\title{
Síndrome de Hoflund em bovino jovem: relato de caso
}

Gilson Antônio Pessoa", Daniel Fantinel Rodrigues, Jerbeson Hoffmann da Silva, Vanessa de Lima, Milana Paese, Elisa Nappi Biasin, Guilherme Novello, Bárbara Guzzon

Universidade de Caxias do Sul (UCS), Caxias do Sul, RS, Brasil

*Autor correspondente

e-mail: gilsonpessoavet@yahoo.com.br

\section{Resumo}

O termo indigestão vagal ou síndrome de Hoflund compreende distúrbios motores que dificultam a passagem de alimento desde a cavidade ruminorreticular. Estes distúrbios ocorrem por um comprometimento do nervo vago. A sintomatologia destes casos depende do local da lesão do nervo. 0 tronco ventral inerva a parte cranial e medial do retículo, omaso e abomaso, resultando em acalasia do piloro e inibição do fluxo da ingesta do abomaso. Já o ramo dorsal inerva rúmen e partes dorsais das outras porções do estômago, causando acalasia orifício retículo-omasal. Foi atendido no ambulatório de grandes animais do curso de medicina veterinária da Universidade de Caxias do Sul, uma fêmea bovina, Limousin, com 10 meses de idade. A queixa principal do proprietário era ocorrência de timpanismo bilateral recorrente desde o nascimento do animal. 0 mesmo relatou a morte de outros cinco animais jovens, apresentando a mesma sintomatologia clínica. No exame clínico geral, o animal apresentou-se apático, apetite regular, diarreia, escore de condição corporal 3 (escala de 1 a 5), frequência cardíaca e respiratória aumentadas, mucosas congestas, desidratação $5 \%$ e tempo de preenchimento capilar normal. No exame físico específico do sistema digestivo, o paciente apresentou aumento abdominal bilateral, hipomotilidade ruminal e bradicardia. Ao realizar a sondagem oroesofágica, constatou-se a presença de conteúdo pastoso com odor fétido, e o resultado da análise de pH do líquido ruminal foi de 6,5. Com os resultados encontrados no exame físico especifico, optou-se pela realização do teste de atropina, tendo este resultado positivo, com aumento da frequência cardíaca de $36 \%$ aos 15 minutos pós-aplicação. Após realização do exame clínico geral e específico, o animal foi internado e o tratamento instituído se baseou no uso de fluidoterapia, antibioticoterapia e tratamento suporte. 0 animal veio a óbito sete dias após a internação no hospital. Na necropsia, observou-se a presença de fibrina na cavidade abdominal e estenose do orifício omaso-abomasal e do piloro. As estenoses observadas na necropsia são lesões que acompanham a síndrome de Hoflund, a qual é considerada uma complicação da reticulite. 
Não foi possível determinar a origem da peritonite, pois nenhum corpo estranho foi encontrado durante a necropsia. Os animais acometidos pela indigestão vagal por tempo prolongado perdem suas condições físicas porque a ausência de trânsito alimentar produz estado de inanição. A atonia explica a consequente sobrecarga ruminal e o estado pastoso das fezes, pois o conteúdo não digerido acaba funcionando como causador de diarreia osmótica. 0 quadro de peritonite é apontado como uma possível causa para lesão vagal. Dessa forma, o diagnóstico de síndrome de Hoflund foi baseado nas evidências clínicas e de necropsia. 